\title{
An Improved Procedure for the Preparation of Poziotinib
}

\author{
CAI Zhi-qiang* \\ School of Petrochemical Engineering \\ Shenyang University of Technology \\ Liaoyang, China \\ e-mail: kahongzqc@163.com \\ MA Wei-ying \\ School of Petrochemical Engineering \\ Shenyang University of Technolog \\ Liaoyang, China \\ e-mail: maweiying88@163.com
}

\author{
HOU Xu \\ School of Petrochemical Engineering \\ Shenyang University of Technology \\ Liaoyang, China \\ e-mail: liaohualiaohua123@163.com
}

\begin{abstract}
Objective: To improve the synthetic procedure of the anticancer drug poziotinib. 2. Methods: The poziotinib was synthesized in six stages starting from 7-methoxy-4-oxo3,4-dihydroquinazolin-yl acetate (2) by chlorinated, ammonification, hydrolysis, condensation, take off Boc and amidation reaction. Compound 2 reacted with $\mathrm{POCl} 3$ followed by ammonification to afford 8. Compound 8 reacted with ammonia water in methanol to obtain 9 which passes through the condensation reaction to obtain 6. Compound 6 took off Boc in the CF3COOH followed by amidation reaction to afford the poziotinib. Results: The anticancer drug poziotinib was synthesized by using 7 methoxy-4-oxo-3,4-dihydroquinazolin-yl acetate as starting material in 6 steps. The structures were characterized by $1 \mathrm{H}$ NMR and ESI-MS. 4. Conclusion: The starting material is very easy to get, the reaction conditions are moderate and the operation is convenient. The reaction steps are shortened and the overall yield is $37.2 \%$. This method is suitable for industrial producing.
\end{abstract}

Keywords-poziotinib; anticancer activity; quinazoline; epidermal growth factor receptor; synthesis

\section{INTRODUCTION}

The epidermal growth factor receptor (EGFR) family of receptor tyrosine kinases has been implicated in a variety of cancers. In particular, activating mutations such as the L858R point mutation in exon 21 and the small inframe deletions in exon 19 of the EGFR tyrosine kinase domain are correlated with sensitivity to EGFR tyrosine kinase inhibitors in non-small cell lung cancer (NSCLC) patients[1-4]. Poziotinib 1, a highly potent, and orally bioavailable inhibitor of human epidermal growth factor receptors $\mathrm{HER}_{1}, \mathrm{HER}_{2}$, and $\mathrm{HER}_{4}$ tyrosine kinase, was developed in a late-stage clinic trial for the prevention and treatment of patients with NSCLC including clinical limitation caused by acquired mutation (EGFR T790M), breast cancer and gastric cancer by Hanmi Science Co., Ltd[5-7]. It could be marketed for the treatment of advanced solid tumors as a new-generation anticancer.

Poziotinib combined with 5-fluorouracil, cisplatin, paclitaxel, or gemcitabine showed a synergistic inhibitory effect on the $\mathrm{HER}_{2}$-amplified and on some of the $\mathrm{HER}_{2-}$ nonamplified breast cancer cells[8-10]. Poziotinib could be a promising treatment for $\mathrm{HER}_{2}$-amplified breast cancer as a single agent or in combination with cytotoxic agents and can be a candidate for treatment of $\mathrm{HER}_{2}$ nonamplified breast cancer in combination with cytotoxic agents[11-12].

Additionally, poziotinib shows an excellent efficacy in a variety of EGFR- and $\mathrm{HER}_{2}$-dependent tumor xenograft models, including erlotinib-sensitive HCC827 NSCLC cells, erlotinib-resistant NCI-H1975 NSCLC cells, HER overexpressing Calu-3 NSCLC cells, NCI-N87 gastric cancer cells, SK-Ov3 ovarian cancer cells and EGFRoverexpressing A431 epidermoid carcinoma cancer cells[13-17]. On the basis of these preclinical results, poziotinib is the most potent pan-HER inhibitor, which will be advantageous for the treatment of patients with NSCLC including clinical limitation caused by acquired mutation (EGFR T790M), breast cancer and gastric cancer[18-22].

In2008, BANG et al. reported a strategy for the synthesis of 1 (Fig .1)[23]. In the process of the synthesis of intermediates 4,3 reacted with $\mathrm{NH}_{3} / \mathrm{MeOH}$ to afford chlorinated products. In the Fig .1, the compound $\mathbf{6}$, as a key intermediate, was prepared from 4 with $\mathrm{Ph}_{3} \mathrm{P}$ and $\mathrm{DEAD}$ reagent to obtain compound $\mathbf{5}$, which is difficult to be purified in the process of separation, and it is need to use chromatographic column. Then, compound $\mathbf{5}$ reacted with 3,4-dichloro-2-fluoroaniline to affort $\mathbf{6}$. This related method has severe drawbacks, limiting the large-scale synthesis of 1: (a) the use of expensive $\mathrm{NH}_{3} / \mathrm{MeOH}$, (b) chromatographic column separation. Accordingly, this synthetic method cannot meet the demand of a large-scale preparation of $\mathbf{1}$ in terms of cost and hazard generation.

As part of the process of bringing a new active pharmaceutical ingredient (API) to market, it often requires use of an alternative synthetic strategy to the initial medicinal chemistry approach. Herein, we report a dramatically improved method for the preparation of poziotinib from the cheap 7-methoxy-4-oxo-3,4 dihydroquinazolin-yl acetate as starting material in an 
overall yield of $37.2 \%$ (Fig .2). In a certain degree, the method eliminates the use of chromatographic column separation. Therefore, the strategy has displayed its practical application potential.

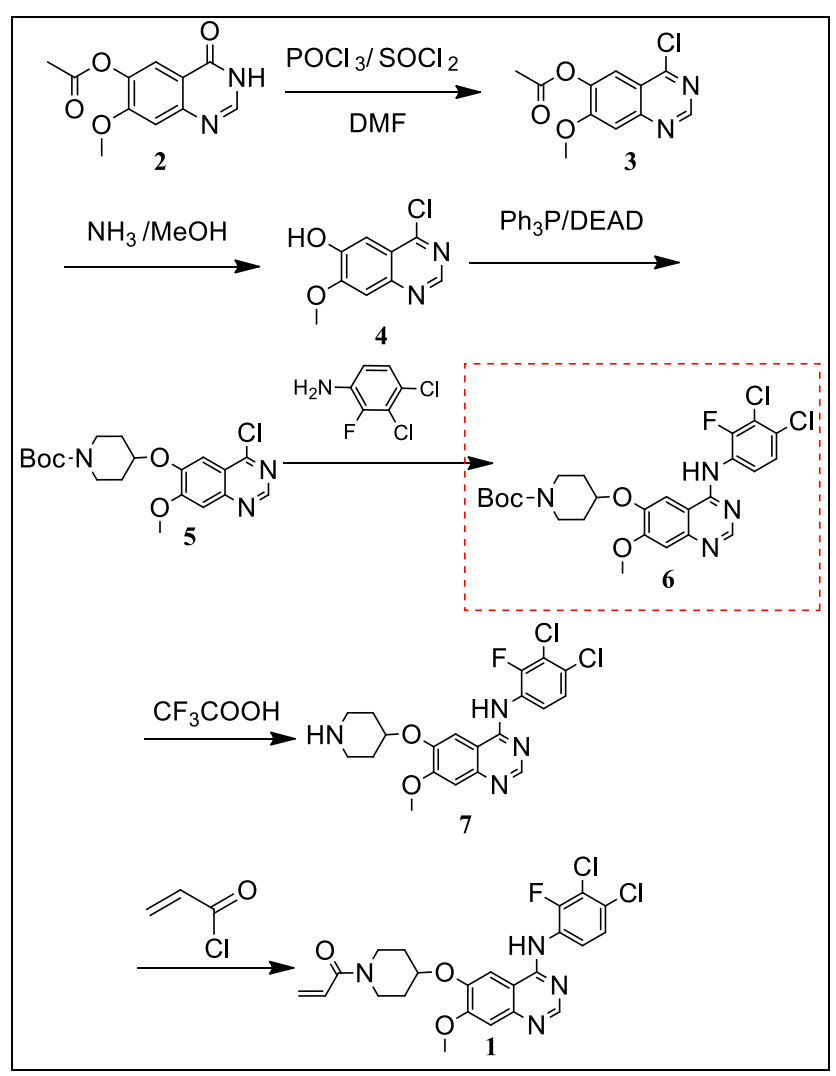

Figure 1. Reported synthetic route to poziotinib.

\section{EXPERIMENTAL}

${ }^{1} \mathrm{H}-\mathrm{NMR}$ spectra were recorded on a Bruker spectrometer at $400 \mathrm{MHz}$, and the chemical shifts were reported as $d$ values in parts per million relative to tetramethylsilane (TMS) as an internal standard. Mass spectra were recorded on Finnigan Trace Ms mass spectrometer. All solvents and reagents were obtained from commercial sources and used without further purification. Thin-layer chromatography(TLC) was performed on silica-gel plates $\left(\mathrm{HF}_{254}\right)$, and TLC visualizations were performed with ultraviolet (UV) light.

Preparation of 4-(3,4-dichloro-2-fluorophenyIamino)7- methoxyquinazolin-6-yl acetate (8) 7-methoxy-4-oxo3,4-dihydroquinazolin-yl acetate (10 g, $0.04 \mathrm{~mol})$ was added to toluene $(250 \mathrm{ml})$ and $\mathrm{Et}_{3} \mathrm{~N}(15 \mathrm{ml})$. Phosphorusoxy chloride $(10 \mathrm{ml})$ was added at $80{ }^{\circ} \mathrm{C}$, followed by stirring for 2 hours. 3,4-dichloro-2fluoroaniline $(7.0 \mathrm{~g}, 0.039 \mathrm{~mol})$ were added to the resulting mixture, followed by stirring for 3 hours (TLC monitor). Upon completion of the reaction, the resulting mixture was cooled to $25^{\circ} \mathrm{C}$. The solid thus obtained was filtered under a reduced pressure. Isopropanol $(180 \mathrm{ml})$ was added to the solid, which was then stirred for 2 hours(TLC monitor). The resulting solid was filtered. The solid was dried at $50{ }^{\circ} \mathrm{C}$ in an oven to produce the compound of $\mathbf{8}$ (16 g, yield: $94.6 \%$ ) as a brown powder. ${ }^{1} \mathrm{H}-\mathrm{NMR}$ (DMSO-d 6 , $400 \mathrm{MHz}, \mathrm{ppm}) \delta 8.91(\mathrm{~s}, 1 \mathrm{H}), 8.73(\mathrm{~s}, 1 \mathrm{H})$, 7.55- $7.68(\mathrm{~m}, 3 \mathrm{H}), 4.03(\mathrm{~s}, 3 \mathrm{H}), 2.35$ (s, 3H); ESI-MS $\mathrm{m} / \mathrm{z}: 396[\mathrm{M}+\mathrm{H}]^{+}$

Preparation of 4-(3,4-dichloro-2-fluorophenylamino)$7-$ methoxyquinazolin-6-ol

(9)4-(3,4-dichloro-2fluorophenylamino)-7-methoxyquinazolin-6-yl acetate (16 $\mathrm{g}, 0.04 \mathrm{~mol})$ was admixed with methanol $(500 \mathrm{ml})$. The mixture was cooled to 10 to $15{ }^{\circ} \mathrm{C}$, added with an ammonia solution $(90 \mathrm{ml})$, and stirred for 1 hours at $25^{\circ} \mathrm{C}$. The solid thus obtained was filtered and washed with a mixed solvent of methanol $(30 \mathrm{ml})$ and water $(30 \mathrm{ml})$. The resulting solid was dried at $50{ }^{\circ} \mathrm{C}$ in an oven to produce 9 (12.6 g, yield: $88.1 \%$ ) as a white powder. ${ }^{1} \mathrm{H}-\mathrm{NMR}$ (DMSO-d $\left.{ }_{6}, 400 \mathrm{MHz}, \mathrm{ppm}\right) \delta 9.53(\mathrm{br}, 2 \mathrm{H}), 8.38(\mathrm{~s}, 1 \mathrm{H})$, $7.62(\mathrm{~s}, 1 \mathrm{H}), 7.50-7.63(\mathrm{~m}, 2 \mathrm{H}), 7.19$ (s, 1H), 4.01 (s, 3H); ESI-MS m/z: $354[\mathrm{M}+\mathrm{H}]^{+}$.

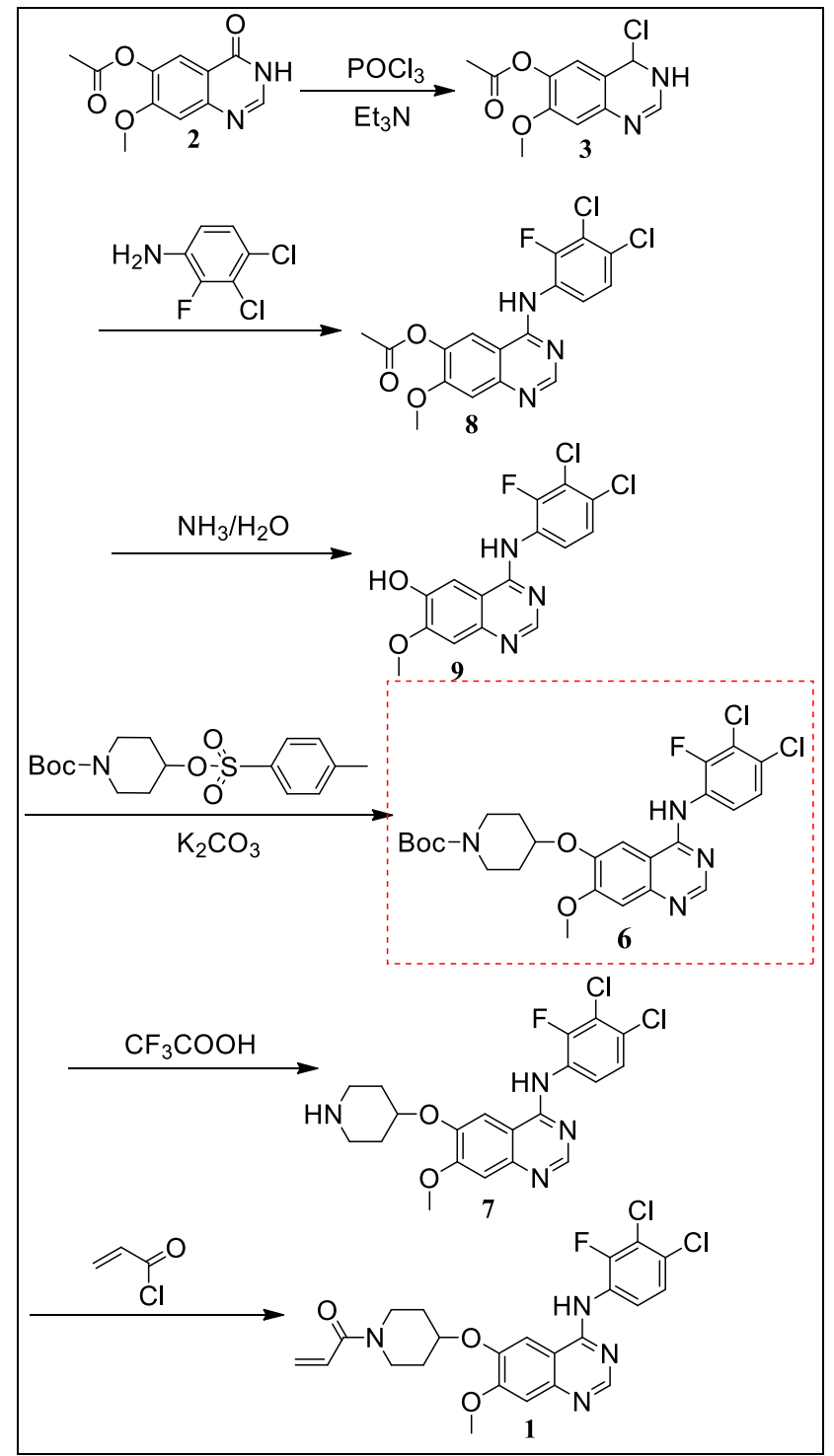

Figure 2. Alternate route to the synthesis of poziotinib.

Preparation of tert-butyl 1-4-(4-(3,4-dichloro-2fluorophenylamino)-7-methoxyquinazolin-6-yloxy) piperidin-1-carboxylate (6) 4-(3,4-dichloro-2fluorophenylamino)-7-methoxyquinazolin-6-ol (12.6 g, $0.036 \mathrm{~mol})$ was admixed with $\mathrm{N}, \mathrm{N}$-dimethylformamide $(80$ ml) under stirring, followed by addition of tert-butyl 4(tosyloxy)piperidin-1-carboxylate (15 g, $0.042 \mathrm{~mol})$ and 
potassium carbonate $(15 \mathrm{~g}, 0.113)$ to the mixture. The reaction temperature was raised to $90{ }^{\circ} \mathrm{C}$, and the mixture was stirred for 3 hours(TLC monitor). The temperature of the resulting solution was cooled to $25^{\circ} \mathrm{C}$, and water $(160$ $\mathrm{ml}$ ) was slowly added thereto. The solid thus obtained was filtered and dried. The solid was dissolved in a mixed solvent $(220 \mathrm{ml})$ of dichloromethane and methanol, followed by stirring for $2 \mathrm{~h}$. The resulting mixture was filtered through a Celite pad, distilled under a reduced pressure, added with acetone $(75 \mathrm{ml})$, and stirred for 6 hours. The resulting solid was filtered and washed with acetone $(20 \mathrm{ml})$. The solid was dried at $40^{\circ} \mathrm{C}$ in an oven to produce 6 (14.2 g, yield: $74.3 \%)$ as a yellowish-brown powder. ${ }^{1} \mathrm{H}-\mathrm{NMR}$ (DMSO-d $\left.6,400 \mathrm{MHz}, \mathrm{ppm}\right) \delta 8.69$ (s, $1 \mathrm{H}), 8.47(\mathrm{t}, 1 \mathrm{H}), 7.34-7.29(\mathrm{~m}, 2 \mathrm{H}), 7.20(\mathrm{~s}, 1 \mathrm{H}), 4.63-$ $4.60(\mathrm{~m}, 1 \mathrm{H}), 3.82(\mathrm{~s}, 3 \mathrm{H}), 3.83-3.76(\mathrm{~m}, 2 \mathrm{H}), 3.37-3.29$ (m, 2H), 1.99-1.96 (m, 2H), 1.90-1.84 (m, 2H), 1.48 (s, 9H) ; ESI-MS m/z: $537[\mathrm{M}+\mathrm{H}]^{+}$.

TABLE I. PERCENT OF $\mathbf{3}$ CONVERSION IN DIFFERENT CHLORINATED REAGENTS

\begin{tabular}{|c|c|c|c|c|}
\hline \multirow{2}{*}{ Entry } & \multicolumn{4}{|c|}{$\begin{array}{c}\text { Percent of 3 Conversion in Different } \\
\text { Chlorinated Reagents }\end{array}$} \\
\cline { 2 - 5 } & $\begin{array}{c}\text { Chlorinated } \\
\text { reagents }\end{array}$ & Temp $\left({ }^{\circ} \mathrm{C}\right)$ & Time(h) & Conversion(\%) \\
\hline 1 & $\mathrm{SOCl}_{2} / \mathrm{Et}_{3} \mathrm{~N}$ & 90 & 8 & 78 \\
\hline 2 & $\mathrm{PCl}_{3} / \mathrm{Et}_{3} \mathrm{~N}$ & 110 & 10 & 15 \\
\hline 3 & $\mathrm{POCl}_{3} / \mathrm{Et}_{3} \mathrm{~N}$ & 80 & 2 & 95 \\
\hline 4 & $\mathrm{SOCl}_{2}$ & 90 & 8 & 56 \\
\hline 5 & $\mathrm{POCl}_{3}$ & 80 & 2 & 82 \\
\hline
\end{tabular}

Preparation of N-(3,4-dichloro-2-fluorophenyl)-7methoxy-6-(piperidin-4-yloxy)quinazolin-4-amine (7) Acetone $(50 \mathrm{ml})$ was added to tert-butyl 4-(4-(3,4dichloro-2- fluorophenylamino)-7-methoxyquinazolin-6yloxy)piperidin-1-carboxylate $(14.2 \mathrm{~g}, 0.026 \mathrm{~mol})$, which was then stirred. The mixture was added with $\mathrm{CF}_{3} \mathrm{COOH}$ $(30 \mathrm{ml})$ for 20 minutes and stirred for 8 hours(TLC monitor). Upon completion of the reaction, the resulting mixture was concentrated, and the resulting solid thus obtained was washed with acetone $(20 \mathrm{ml})$. The solid was dried at $50^{\circ} \mathrm{C}$ in an oven to produce $7(11 \mathrm{~g}$, yield: $95.2 \%)$ as a yellowish powder. ${ }^{1} \mathrm{H}-\mathrm{NMR}$ (DMSO-d $6,400 \mathrm{MHz}$, ppm) $\delta 12.88$ (bs, 1H), 9.39 (bs, 1H), 9.21 (bs, 1H), 9.05 $(\mathrm{s}, 1 \mathrm{H}), 8.89(\mathrm{~s}, 1 \mathrm{H}), 7.55-7.72(\mathrm{~m}, 2 \mathrm{H}), 7.38(\mathrm{~s}, 1 \mathrm{H})$, 5.05- $5.12(\mathrm{~m}, 1 \mathrm{H}), 4.02(\mathrm{~s}, 3 \mathrm{H}), 3.19-3.30(\mathrm{~m}, 4 \mathrm{H}), 2.28-$ 2.31 (m, 2H), 1.90-1.97 (m, 2H) ; ESI-MS m/z: 437 [M + $\mathrm{H}]^{+}$.

Preparation of 1-(4-(4-(3,4-dichloro-2fluorophenylamino)-7-methoxyquinazolin-6-yloxy)piperidin-1-yl)prop2-en-1-one (poziotinib , 1)N-(3,4-dichloro-2-fluorophenyl) -7-methoxy-6-(piperidin-4-yloxy)quinazolin-4-amine dihydrochloride $(11 \mathrm{~g}, 0.025 \mathrm{~mol})$ and sodium hydrogen carbonate $(8 \mathrm{~g}, 0.095 \mathrm{~mol})$ were added to a mixed solvent of tetrahydrofuran $(90 \mathrm{ml})$ and water $(120 \mathrm{ml})$, and the temperature of the reaction mixture was cooled to $0{ }^{\circ} \mathrm{C}$ with iced water. Acryloyol chloride $(3 \mathrm{ml}, 0.037 \mathrm{~mol}$ ) diluted with tetrahydrofuran $(50 \mathrm{ml})$ was slowly added to the reaction mixture over 50 minutes, followed by stirring at $0{ }^{\circ} \mathrm{C}$ for $2 \mathrm{~h}$ (TLC monitor). Upon completion of the reaction, aqueous acetone $(200 \mathrm{ml})$ was added to the resulting mixture, which was stirred for 24 hours and filtered to produce $\mathbf{1}$ as a yellowish-brown powder. The solid thus obtained was dissolved in a mixed solvent of dichloromethane $(20 \mathrm{ml})$ and methanol $(10 \mathrm{ml})$, added with ethyl acetate $(120 \mathrm{ml})$, and stirred for 24 hours. The resulting solid was filtered and washed with ethyl acetate $(10 \mathrm{ml})$. The solid was dried at $50^{\circ} \mathrm{C}$ in an oven to produce $\mathbf{1}(7.8 \mathrm{~g}$, yield: $63.1 \%)$ as a white powder. ${ }^{1} \mathrm{H}$ NMR (DMSO-d $\left.{ }_{6}, 400 \mathrm{MHz}, \mathrm{ppm}\right) \delta 8.66(\mathrm{~s}, 1 \mathrm{H}), 8.37(\mathrm{t}$, $3 \mathrm{H}), 7.29(\mathrm{~m}, 3 \mathrm{H}), 6.63(\mathrm{~m}, 1 \mathrm{H}), 6.25(\mathrm{~m}, 1 \mathrm{H}), 5.70(\mathrm{~m}, 1 \mathrm{H})$, 4.72(m, $1 \mathrm{H}), 4.01(\mathrm{~s}, 3 \mathrm{H}), 3.86(\mathrm{~m}, 2 \mathrm{H}), 3.57(\mathrm{~m}, 2 \mathrm{H})$, 1.88(m, 4H) ; ESI-MS m/z: $491[\mathrm{M}+\mathrm{H}]^{+}$.

\section{RESULTS AND DISCUSSION}

In the medicinal chemistry approach, the key intermediate $\mathbf{6}$ was synthesized in four stages starting from 7-methoxy-4-oxo-3,4-dihydroquinazolin-yl acetate 2 as shown in Fig .2. In the first step, chlorinated product 3 was generated by the addition of chlorinated reagents to a solution of $\mathbf{2}$ in toluene followed by addition of 3,4dichloro-2-fluoroaniline to afford $\mathbf{8}$. Compound 8 was reacted with alkali liquor in methanol at $25{ }^{\circ} \mathrm{C}$ for $1 \mathrm{~h}$. $\mathrm{NH}_{3} / \mathrm{H}_{2} \mathrm{O}$ was found to be good in terms of alkalic system. In the next stage, 9 was treated with tert-butyl 4(tosyloxy)piperidin-l-carboxylate in DMF, and then the reaction mixture was added to $\mathrm{H}_{2} \mathrm{O}$ to afford 6 .

In the synthesis of $\mathbf{3}$, we investigated the reaction in different chlorinated reagents viz. $\mathrm{SOCl}_{2}, \mathrm{PCl}_{3}$, and $\mathrm{POCl}_{3}$ (Table I). As seen in Table I, reaction was relatively slow, and conversion to product was not satisfactory in either $\mathrm{SOCl}_{2}$, or $\mathrm{PCl}_{3}$ chlorinated reagents. Reaction in $\mathrm{POCl}_{3}$ was very good. In the case of $\mathrm{POCl}_{3}$, the reaction mixture was acidic; it was necessary to add $\mathrm{Et}_{3} \mathrm{~N}$ to afford $\mathbf{3}$

\section{CONCLUSION}

It is worth noting that we had carried out significant developmental work on the medchem approach with minimal changes to the route of synthesis. These key changes in the process made significant impact on yield, time, and environmental aspects. In summary, we have developed an efficient process for largescale manufacturing of poziotinib through a convenient approach.

\section{ACKNOWLEDGMENT}

The authors are grateful to the Doctoral Start-Up Fund of Shenyang University of Technology(NO. 521422) for the financial support of the investigation.

\section{REFERENCES}

[1] H. J. Nam, H. K. Kim, and Y. K. Yoon, et al, "Antitumor activity of HM781-36B, an irreversible Pan-HER inhibitor, alone or in combination with cytotoxic chemotherapeutic agents in gastric cancer", vol. 302. Elsevier: Cancer Letters, Jan. 2011, pp.155-165, doi:10.1016/j.canlet.2011.01.010.

[2] R. Rosell, M. A. Molina, C. Costa, et al, "Pretreatment EGFR T790M mutation and BRCA1 mRNA expression in erlotinibtreated advanced non-small-cell lung cancer patients with EGFR 
mutations", vol. 17. Clin Cancer Res, Mar.2011, pp:1160-1168, PMID:21233402.

[3] V. A. Miller, V. Hirsh, J. Cadranel, et al, "Afatinib versus placebo for patients with advanced, metastatic non-small-cell lung cancer after failure of erlotinib, gefitinib, or both, and one or two lines of chemotherapy (LUX-Lung 1): a phase $2 \mathrm{~b} / 3$ randomised trial", vol. 13. Lancet Oncol, Mar. 2012, pp:528-538, PMID:22452893.

[4] M. Wang, J. Zhao, L. M. Zhang, et al, "Combined erlotinib and cetuximab overcome the acquired resistance to epidermal growth factor receptor tyrosine kinase inhibitor in non-small-cell lung cancer", vol. 138. J Cancer Res Clin Oncol, Dec. 2012, pp:20692077, PMID:22827179.

[5] J. Remon, T. Moran, and M. Majem, et al, "Acquired resistance to epidermal growth factor receptor tyrosine kinase inhibitors in EGFR-mutant non-small cell lung cancer: A new era begins", vol. 40. Elsevier: Cancer Treatment Reviews, Jun. 2014, pp.93-101, doi:10.1016/j.ctrv.2013.06.002

[6] K. W. Robinson, A. B. Sandler, "The role of MET receptor tyrosine kinase in non-small cell lung cancer and clinical development of targeted anti-MET agents", vol. 18. The Oncologist, Jun. 2013, pp:115-122, doi:10.1634/theoncologist. 2012-0262.

[7] H. P. Kim, Y.K. Yoon, and J. W. Kim, et al, "Lapatinib, a dual EGFR and HER2 tyrosine kinase inhibitor, downregulates thymidylate synthase by inhibiting the nuclear translocation of EGFR and HER2", vol. 4. PLoS One, Jun. 2009, pp.e9533, doi:10.1371/journal.pone.0005933.

[8] H. J. Kim, H. P. Kim, and Y. K. Yoon, et al, "Antitumor activity of HM781-36B, a pan-HER tyrosine kinase inhibitor, in HER2amplified breast cancer cells", vol. 23. Anti-Cancer Drugs, Oct. 2012, pp.288-297, doi:10.1097/cad.0b013e32834e7d9b.

[9] L. Daniel, Strategies for Organic Drug Synthesis and Design, Wiley-Interscience, 2008, pp. 440-444, ISBN:9780470190395.

[10] R. Nahta, L. X. Yuan, and B. Zhang, et al, "Insulin-like growth factor-1 receptor/human epidermal growth factor receptor 2 heterodimerization contributes to trastuzumab resistance of breast cancer cells", vol. 65. Cancer Res, Dec. 2005, pp.11118-11128, PMID:16322262.

[11] K. L. Tedesco, A. C. Lockhart, and J. D. Berlin, "The epidermal growth factor receptor as a target for gastrointestinal cancer therapy", vol. 5. Current Treatment Options in Oncology, Oct. 2004, pp.393-403, doi:10.1007/s11864-004-0029-z.

[12] G. R. Oxnard, M. E. Arcila, and C. S. Sima, et al, "Acquired resistance to EGFR tyrosine kinase inhibitors in EGFR-mutant lung cancer: distinct natural history of patients with tumors harboring the T790M mutation”, vol. 17. Clinical Cancer Research, Dec. 2010, pp.1616-1622, doi:10.1158/1078-0432.CCR-10-2692.

[13] A. Wells, "EGF receptor", vol. 31. Int J Biochem Cell Biol, Jun. 1999, pp.637-643, PMID:10404636.

[14] J. Mendelsohn, J. Baselga, "The EGF receptor family as targets for cancer therapy”, vol. 19. Oncogene, Jan. 2001, pp.6550-6565, doi:10.1038/sj.onc.1204082.

[15] R. Rosell, T. Moran, and C. Queralt, et al, "Screening for Epidermal Growth Factor Receptor Mutations in Lung Cancer", vol. 361. N Engl J Med, Sep. 2009, pp.958-967, doi:10.1056/NEJ Moa0904554.

[16] D. Raben, L. B. Cmilas, and K. K. Ang, et al, "Targeted therapies and radiation for the treatment of head and neck cancer: are we making progress?", vol. 14. Seminars in radiation oncology, Apr. 2004, pp.139-152, doi:10.1016/s0022-0248(97)00350-3.

[17] R. Berardi, M. Santoni, and F. Morgese, et al, "Novel small molecule EGFR inhibitors as candidate drugs in non-small cell lungcancer", vol. 6. Dovepress: OncoTargets and Therapy, May. 2013, pp.563-576, doi:10.2147/OTT.S28155.

[18] E. M. Berman, L. M. "Werbel, The Renewed Potential for Fo-late Antagonists inContemporary Cancer Chemotherapy", vol. 34. J.Med.Chem, Feb. 1991, pp.479-485, doi:10.1021/jm00106a001.

[19] H. Uramoto, T. Yamada, S. Yano, et al, "Prognostic value of acquired resistance-related molecules in Japanese patients with NSCLC treated with an EGFR TKI", vol. 32. Anticancer Res, Sep. 2012, pp:3785-3790, PMID:22993320.

[20] D. Ercan, C. Xu, M. Yanagita, et al, "Reactivation of ERK signaling causes resistance to EGFR kinase inhibitors", vol. 2. Cancer Discover, Sep. 2012, pp:934-947, doi:10.1158/21598290.CD-12-0103.

[21] M. Nishino, S. Cardarella, S. E. Dahlberg, et al. "Radiographic assessment and therapeutic decisions at RECIST progression in EGFR-mutant NSCLC treated with EGFR tyrosine-kinase inhibitors", vol. 79. Lung Cancer, Nov. 2012, pp:283-288, doi:10.1016/j.lungcan.2012.11.007.

[22] A. Sekine, T. Kato , E. Hagiwara, et al, "Metastatic brain tumors from non-small cell lung cancer with EGFR mutation: distinguishing influence of exon 19 deletion or radiographic features", vol. 77. Lung cancer, Feb. 2012, pp:64-69, doi:10.1016/j.lungcan.2011.12.017.

[23] L. Kwang-Ok, C. M. Young, and K. M. Ra, et al, Novel Amide Derivative for linhibiting the Growth of Cancer Cells, WO, 2008150118, 2008.11.12 